\title{
What have we learned about ecological recovery from liming interventions of acid lakes in Canada and Italy?
}

\author{
Marina M. MANCA, ${ }^{1}$ Carla BONACINA, ${ }^{1}$ Norman D. YAN ${ }^{2}$ \\ ${ }^{1}$ National Research Council, Institute of Ecosystem Study, Largo Tonolli 50, 28922 Verbania Pallanza (VB), Italy; ${ }^{2}$ Biology Department,
} York University, Toronto, Ontario, and Dorset Environmental Science Centre, Box 39, Dorset, Ontario, Canada, P0A 1E0

\begin{abstract}
The idea of launching another special issue of the Journal of Limnology on Lake Orta was born in 2014, on the $25^{\text {th }}$ anniversary of its liming intervention, during an International Symposium on Lake Orta organized and hosted by the Pallanza Institute (http://www.ise.cnrit/vb). The conference did not simply celebrate the past. While the liming of Lake Orta was undoubtedly a great national and international success, the speakers at the conference, instead sought to enlarge and deepen knowledge of patterns and mechanisms of lake ecosystem responses to the water quality improvements, or chemical recovery, that accompanied Lake Orta's liming.
\end{abstract}

\section{THE ECOSYSTEM PERSPECTIVE}

We adopted an ecosystem perspective, by: i) exploring timing and mechanisms through which the biota responded to changes in hydrochemistry; ii) identifying common versus unique responses in a comparison of similar case studies on a large scale; iii) disentangling specific roles of primary (heavy metals) $v s$ secondary (acidification), direct (chemical) vs indirect (predator/prey), and regional (colonist supply) vs local (colonist survival and growth) regulators of recovery of the biota; and iv) attempting to identify transition points to new, stable communities. If we can circumvent the almost unavoidable issue of lack of replication, and include appropriate hypotheses, controls, and pre- and post-manipulation data, a liming intervention can be comparable to a whole lake experiment. It can provide an opportunity for testing ecosystem-level responses to strictly controlled changes in the physical and chemical environment. Such wholelake experiments have a long tradition in North America, but it is rare that the results of whole-lake restoration experiments in the acidification field have been compared between North America and Europe.

Lake Orta and many lakes in Sudbury, Ontario, Canada, suffered from acidification and metal pollution, albeit from different sources. For Lake Orta, the source of acidity was oxidation of ammonia wastes from a textile factory (Bonacina et al., 1986), while for Sudbury lakes, the source was atmospheric deposition of strong, S-based acidity from both the local smelting of metal-rich sulphide ores and long-range transport (Yan et al., 1996). Heavy metals were also greatly elevated in both cases (Calderoni et al., 1992; Keller et al., 2007). In Sudbury, both catchments and several urban lakes were limed, while lime was added directly to Lake Orta.

This comparison of Lake Orta with the Sudbury case studies was extremely fruitful. By applying bioassays, Celis-Salgado et al. (2016) found that differences in metal-tolerances, and differences in recovery rates of native Canadian Daphnia species were mediated by calcium and sodium concentrations in Sudbury lakes, and thus their recovery was influenced not just by residual metals, but also by road salt and background geology. From Lake Orta, Di Cesare et al. (2016) learned that because heavy metal pollution may be coupled with antibiotic presence in nature, there may be co-selection for multiple resistances. Lake Orta thus appears to be an excellent location to evaluate the spread and selection of heavy metals and antibiotic resistances in heavily disturbed environments.

Macrobenthic assemblages were slow to recover in both countries, but there were success stories. In Sudbury lakes the littoral macrobenthos community remained severely impoverished after catchment liming, indicating that land reclamation would be necessary in severely damaged watershed, before lake ecosystems can recover (Gunn et al., 2016). In Lake Orta, mussels were extirpated by industrial copper and ammonium sulphate pollution, soon after 1926, when a rayon factory began operations on the lakeshore. Severe acidification and metal pollution likely prevented their recovery for many decades. Even after liming restoring water quality in 1989-1990, molluscs were not detected, but then mussels do not recolonize easily, particularly if they lack access to restocking populations and/or their dispersal/recruitment is limited by inadequate abundance of necessary hosts. However, live mussels have recently reinvaded Lake Orta, and their presence was noted in a video posted on a social network. Riccardi et al. (2016) confirmed the presence of live Unio elongatulus in Lake Orta over one century since the previous and only record. Investigating the how and when of the reappearance of Unio elongatulus in the lake, Riccardi et al. (2016) compared Lake Orta's Unio haplotypes with 
those of other Northern Italian populations, and estimated the age of the larger and seemingly older individuals. They concluded that colonizing mussels were likely transported into the lake by fish, carrying Glochidia, that had been stocked into the lake after liming.

Lake Orta's sediments may still pose a toxic threat to benthic species. Vignati et al. (2016) noted that Lake Orta's sediments still pose a potential risk of $\mathrm{Cu}$ toxicity to sediment-ingesting benthic organisms. They argued we need more information on $\mathrm{Cu}$ behaviour and bioavailaility as a function of sediment characteristics in order to rule out subtle and lasting effect on benthic species and communities.

Rogora et al. (2016) updated the chemical status of Lake Orta for the 25 years since liming, and confirmed the overall recovery of water quality. The restoration of typical seasonal changes in $\mathrm{pH}$, and concentrations of nitrate and phosphorus compounds confirmed normal regulation by algal uptake, while seasonal changes in reactive silica implicated a productive diatom community.

Understanding the responses of lakes to reductions of pollution and restorative interventions requires long-term research and monitoring, only rarely achieved. Similarly to Lake Orta, paleolimnological approaches have been applied to Sudbury lakes, and have complemented and enriched the observational records. Some key taxa, such as those of the cladoceran Bosmina genus, are very well preserved in the sedimentary archive, and changes in their morphometrics and abundance can be used to reconstruct population size structure and infer regulation, especially by invertebrate predators, during different phases of pollution and recovery. In the case of the Sudbury lakes, Labaj et al. (2016) interpreted persistent changes to Bosmina size structure as evidence of continued dominance of the food webs by cyclopoid copepods (during acidification and recovery). High resolution analysis of Lake Orta sediment core also provided evidence for persistence of rotifers during periods of contamination, with increased abundance of resting eggs of different morphotypes. Unlike most other organisms, which were extirpated by the pollution of the lake, rotifers survived, producing resting eggs, attempting to secure future generations (Piscia et al., 2012; Piscia et al., 2016b).

The development of resurrection ecology, i.e. the testing of hypotheses using with organisms hatched from resting eggs deposited at different stages of lake evolution, has enriched paleolimnology, and was applied to Lake Orta cores, both for rotifers (Sommer et al., 2016a), and Cladocera (Daphnia; Sommer et al., 2016b). Sommer et al. (2016a) reviewed the current knowledge for rotifers in Lake Orta, using studies on both living organisms and on their resting stages accumulated in the sediments. They noted that rotifers were an excellent ecological and evolutionary model system; they compared observed $v s$ ex- pected changes of acid and copper pollution at the population, species and community level. They suggested resurrection ecology and experimental limnology could be employed as a means to interpret the unexpected, e.g. the persistence of a single Brachionus calyciflorus haplotype in resting eggs. This result suggests that this species did adapt to the polluted conditions in the lake dominating through priority effects and monopolisation (De Meester et al., 2002), while no foreign haplotypes managed to colonise the lake during its fluctuating conditions. Sommer et al. (2016b) estimated vital rates (survival, maturation, and reproduction) of resurrected and contemporary Daphnia, used them to project the asymptotic population growth rates under copper polluted $v s$ unpolluted laboratory conditions. These projections highlighted that a lower probability of reproduction and reduced fecundity was the cost of a higher copper tolerance in resurrected Daphnia. However, higher elasticity values of population growth rates suggest that any change in the environment that will affect survival rather than reproductive parameters will have a much larger impact on Lake Orta's current Daphnia population.

Using an extensive 2014 sampling campaign, the present fish community of Lake Orta was compared to both its pre-pollution composition and to the assemblages of nearby reference lakes, Lake Mergozzo and Lake Maggiore (Volta et al., 2016). While nearshore fish density now appears normal in the lake, the open water community remains impoverished both in numbers and in species, with shad and coregonids and fully or partially migratory species still missing from the lake, likely because of their initial extirpation and blocked re-colonization routes along the outlet River Strona. To propose priorities for fish community restoration in Lake Orta, Volta and colleagues categorized the naturalist, ecological and economic values of each missing fish species in the lake, and evaluated the cost and probability of success of the needed intervention for each species. The analysis indicated that restoration of whitefish and shad should receive highest priority.

The recovery of lakes from severe, historical, acid and metal pollution requires that colonists of extirpated species arrive, survive and subsequently thrive (Yan et al. 2016). An analysis of 40 year records from weekly to monthly crustacean zooplankton samples from Middle and Clearwater lakes near Sudbury, Canada, demonstrated that ecological recovery of zooplankton from acidification and metal pollution in the lakes did not depend strongly on propagule introduction rates which were adequate, but rather varied with propagule persistence, in lake-rich, suburban landscapes such as those near Sudbury. Piscia et al. (2016a) applied the same approach to Lake Orta's crustacean and rotifer zooplankton trajectories and found much higher annual persistence in this lake than in the 
limed lakes in Sudbury. They argued this might be related to the lack of cladoceran predators (Leptodora and Bythotrephes) and zooplanktivorous fish in the pelagic waters of Lake Orta, in contrast to Sudbury lakes.

Finally, Saidi et al. (2016) provided a preliminary analysis of annual and seasonal fluctuations of lake level in Lake Orta, defining trends and temporal fluctuations in water levels from 1917 to 2014.

What have we learned from this comparison of the dynamics of ecological recovery in Lake Orta and Sudbury lakes after liming? Among many things, we have learned:

- that chemical and ecological recovery proceed at very different rates;

- that chemical recovery is a necessary but not certainly a sufficient step for ecological recovery;

- that recovery of lake biota may require restoration of watersheds, if they were also damaged;

- that ecological recovery may require additional interventions, such as fish stocking;

- that unplanned accidents may be critical for ecological recovery, e.g. the stocking of fish with glochidial infestations;

- that predator-prey interactions may remain strong in communities that are impoverished by pollutants;

- that high seasonal persistence of biota may be an indication of continuing ecological impoverishment, not of recovery;

- that the public can play important roles as observers in restoration studies;

- that long-term studies of manipulated systems are great hypothesis generators for subsequent examination by ecotoxicologists, population, and resurrection ecologists;

- that management interventions can provide information of fundamental value to the understanding of lake ecosystems, and;

- that while there has been great progress in the recovery of Sudbury lakes and Lake Orta, their recovery is not yet complete. Key proof of this is the impoverished littoral biota of Sudbury lakes, and the lack of native pelagic zooplanktivorous fish in Lake Orta.

\section{REFERENCES}

Bonacina C, Bonomi G, Mosello R, 1986. Notes on the present recovery of Lake Orta: an acid, industrially polluted, deep lake in North Italy. Mem. Ist. Ital. Idrobiol. 44:97-115.

Calderoni A, Mosello R, Ruggiu D, 1992. Sixty years of limnology on Lago d'Orta: a case history of recovery from heavy pollution. In: P. Guilizzoni, G. Tartari and G. Giussani (eds.), Limnology in Italy. Mem. Ist. Ital. Idrobiol. 50:201-224.

Celis-Salgado MP, Keller WB, Yan ND, 2016. Calcium and sodium as regulators of the recovery of four Daphnia species along a gradient of metal and base cations in metal contaminated lakes in Sudbury, Ontario, Canada. J. Limnol. 75 (Suppl.2):36-49.
De Meester L, Gómez A, Okamura B, Schwenk K, 2002. The monopolization hypothesis and the dispersal-gene flow paradox in aquatic organisms. Acta Oecol. 23:121-135.

Di Cesare A, Eckert E, Corno G, 2016. Co-selection of antibiotic and heavy metal resistance in freshwater bacteria. J. Limnol. 75(Suppl.2):59-66.

Gunn JM, Kielstra BW, Szkokan-Emilson E, 2016. Catchment Liming Creates Recolonization Opportunity for Sensitive Invertebrates in a Smelter Impacted Landscape. J. Limnol. 75(Suppl.2):50-58.

Labaj AL, Korosi JB, Kurek J, Jeziorski A, Keller WB, Smol JP, 2016. The responses of Bosmina size structure to the acidification and subsequent recovery of lakes near Sudbury, Canada. J. Limnol. 75(Suppl.2):22-29.

Keller W, Yan ND, Gunn JM, Heneberry J, 2007. Recovery of acidified lakes: lessons from Sudbury, Ontario, Canada. Water Air Soil Poll. Focus 7:317-322.

Piscia R, Guilizzoni P, Fontaneto D, Vignati DA, Appleby PG, Manca M, 2012. Dynamics of rotifer and cladoceran resting stages during copper pollution and recovery in a subalpine lake. Int. J. Limnol. 48:151-160.

Piscia R, Yan ND, Manca M, 2016a. Mechanisms underlying recovery of zooplankton in Lake Orta after liming. J. Limnol. 75(Suppl.2):15-21.

Piscia R, Tabozzi S, Bettinetti S, Nevalainen L, Manca M, 2016b. Unexpected increaes in rotifer resting egg abundances during the period of contamination of Lake Orta. J. Limnol. 75(Suppl.2):76-85.

Riccardi N, Froufe E, Lopes-Lima M, Mazzoli C, 2016. When and how? Freshwater mussel recolonization in Lake Orta. J. Limnol. 75(Suppl.2):120-130.

Rogora M, Kamburska L, Mosello R, Tartari G, 2016. Lake Orta chemical status 25 years after liming: problems solved and emerging critical issues. J. Limnol. 75(Suppl.2):93-106.

Saidi H, Dresti C, Ciampittiello M, 2016. Fluctuations of Lake Orta water levels: preliminary analyses. J. Limnol. 75 (Suppl.2):86-92.

Sommer S, Piscia R, Manca M, Fontaneto D, Ozgul A, 2016a. Demographic cost and mechanisms of adaptation to environmental stress in resurrected Daphnia. J. Limnol. 75(Suppl.2):30-35.

Sommer S, Nandini S, Sarma SSS, Ozgul A, Fontaneto D, 2016b. Rotifers in Lake Orta: a potential ecological and evolutionary model system. J. Limnol. 75(Suppl.2):67-75.

Vignati DAL, Bettinetti R, Marchetto A, 2016. Long-term persistence of sedimentary copper contamination in Lake Orta: potential environmental risks 20 years after liming. J. Limnol. 75(Suppl.2):107-119.

Volta P, Yan ND, Gunn JM, 2016. Past, present and future of the fish community of Lake Orta (Italy), one of the world's largest acidified lake. J. Limnol. 75(Suppl.2):131-141.

Yan ND, Keller W, Somers KM, Pawson TW, Girard RG, 1996. Recovery of crustacean zooplankton communities from acid and metal contamination: comparing manipulated and reference lakes. Can. J. Fish. Aquat. Sci. 53:1301-1327.

Yan ND, Bailey J, McGeer JC, Manca M, Keller WB1, CelisSalgado MP, Gunn JM, 2016. Arrive, survive and thrive: essential stages in the re-colonization and recovery of zooplankton in urban lakes in Sudbury, Canada. J. Limnol. 75(Suppl.2):4-14. 